\title{
AN OVERVIEW OF THE PHYSICAL AND SOCIAL LEARNING ENVIRONMENT OF NIGERIAN SCHOOLS
}

\author{
Dr. USMAN DA'U ALIYU
}

\begin{abstract}
The paper begins by conceptualizing the concept of physical and social learning environment. Then the paper examines the importance of those learning environments, characteristics of the environments, and effects of poor learning environment. The paper put forward recommendations and concludes that there is no alternative to conductive physical and social environment in the derive to facilitate teaching and learning.
\end{abstract}

\section{Introduction}

The Nigerian educational objectives as contained in National Policy on Education (FRN, 2005) recognized the pivotal role played by education in the overall national development. The actualization of those objectives largely depends on the availability of conducive teaching and learning environment.

According to Udeozor (2002:122) environment is the combination of the natural objects, namely: living and non-living, human-made objects, the interrelationship between these, and various circumstances which surround people on earth. It could be argued then that environment is the basis of all life (Adara, 1988) cited in Udeozor, 2002). Thus, environment has some physical, social, emotional and psychological dimensions.

The physical learning environment consist of all the movable and immovable assets existing in the school on one hand, and those other similar ones facilitating learning at home (Udeozor, 2002:123). Within the school, the physical environment includes the classrooms, offices, staff rooms, toilets, laboratories, sporting facilities, libraries, plants, water, desks and chairs, audio-visual materials, books, light, temperature and any others. The availability and proper utilization of the school facilities stimulates learning.

The social learning environment refers to the relationship between the learner, the immediate family and the significant others. The social factors affecting learning, otherwise known as the social leaming environment, include the family, teacher, peer group, community, society and government. Aliyu (2006) observed that the state of the social environment either facilitates or frustrates learning.

A percieved conducive environment is the one that is characterized by favourable or desirable physical, social, emotional and psychological conditions. This type of environment has the tendency for stimulating teaching and learning. This paper therefore focuses attention on the physical and social learning environment in Nigerian schools, its challenges and possible solutions. 


\section{Importance of Conducive Physical Learning Environment}

Udeozor (2002) enumerated some of the importance of conducive physical learning environments, thus:

i. Academic achievement: An enduring change in behaviour (learning) is achieved as a result of experience gained in a stimulating and satisfying physical environment.

ii. Adjusted behaviour: The absence of a favourable physical learning environment can manifest in maladjusted behaviour. On the other hand, a conducive physical learning environment develops a well adjusted personality.

iii. Emotional and psychological development: A favourable physical learning environment is the one that satisfies the educational and recreational needs of the individual. In this kind of setting the emotional and psychological needs of the learner are adequately satisfied which go a long way to enhance accelerated and permanent learning.

Any physical environment that is lacking in the necessary materials or facilities for learning would have negative influence on the psychological state of the learner and frustration, dissatisfaction might be the result. This will negatively affect the level of academic achievement in particular and personality development in general.

iv. Psychomotor development: The availability of recreational facilities promotes psychomotor development. The opportunity given to the learner to engage in sporting activities enables him to bum out and release excess energy. This improves his physical and mental health condition leading to psychological balance and improved academic achievement.

\section{Importance of conducive Social Learning Environment}

Some of the ways by which the social environment affects academic achievement will be examined below:

i- Academic motivation: The individual develops academic motivation through interaction with the academic environment (Wentzel, 1999, cited in Adeniyi, 2002).

ii- Positive attitude to school: The parental aspiration, education and occupation influence child's attitude to school, (Odebunmi, 1988).

iii- Help seeking behaviuor: Where classrooms are viewed as supportive and friendly, students feel more comfortable interacting with mates and teachers. Familiarity and friendship are important factors as regards whom learners would ask for help (Ryan, Gheen \& Midgely, 1998).

iv- Cognitive development: Cooperative interactions and collaborative problem solving can hasten the development of higher order thinking and specific intellectual skills. Similarly, learning is gained when students acquire information through seeking suggestions or opinions, (Gullies \& Ashman, 1998).

$v-\quad$ School retention: Learner's decision either to remain or leave school is largely determined by social acceptance or rejection respectively. Socially competent children have an advantage of both peer relation and school adjustment. Conversely, 
rejected children have problematic academic profile (Diehi, Lemerise, Cavalry, Ramsay \& Roberts, 1988 cited in Adeniyi, 2002).

\section{An Overview of the Physical Environment of Nigerian School}

As noted above, the physical environment refers to the movable and immovable assets otherwise called school facilities. Ubah (2002:133) reporting many studies (e.g. NPEC and SPU, 1991: UNICEF and FGN, 1993, Girei \& Gerei, 1995) revealed that:

i. many schools have no school buildings;

ii. there is acute shortage of teachers' and pupils' furniture;

iii. most of the pupils had no textbooks at all, while only few had writing materials;

iv. equipment for Science, Agricultural Science, Home Economics, Art and Crafts were lacking in most of the schools;

v. there was serious lack of adequate funding for the renovation of existing school buildings and construction of new ones;

vi. class sizes were too large;

vii. work space was too small;

viii. storage facilities were too limited; and

ix. many pupils learned under very harsh physical conditions such as cold during harmattan and rainy season and heat during the dry season.

Ubah (2002) observed that the physical condition of Nigerian schools was so pathetic that the available financial resources are grossly inadequate to raise the school facilities to a good standard. In otherwords, it will take the various levels of government a long time and resources to ameliorate the physical environment of Nigeria schools.

\section{Effects of Poor Physical Environment on Learning}

The negative effects of poor physical environment on teaching and learning, according to Ubah (2002) include:

i. some parents refuse to send their children to school;

ii. teachers' and pupils' morale are lowered;

iii. it gives the school teacher a poor image;

iv. It lays a weak educational foundation for the children;

v. leads to the falling standard of education;

vi. production of educationally half-baked graduates of the primary school; and

vii. creation of unconducive teaching and learning environment. 


\section{An Overview of the Social Learning Environment:}

It is evident that the social learning environment comprises many of the social groups which include the family, teachers, peer group among others. This section of the paper will dwell on some aspects of the social learning environment as presented below:

i. Family: This is the primary agent of socialization. What the child becomes later in life is largely determined by the quality of care and training received at the early childhood stage. Odunukwe (2002) observed that some negative tendencies at the family level have adversely affected and influenced the life of the Nigerian child. The negative tendencies include the house-help syndrome, broken-home by death, divorce or the prolonged or frequent absence of one of both parents, large number of children, illiteracy, poverty and ignorance. These multiple problems were aggravated by the increasing economic depression among the populace.

The unconducive condition at the family level leads to various negative consequences that include none attendance of school by many children; children with various emotional and behavioural problems are brought up; many children have problems adapting to classroom programmes and many children engage in anti-social behaviours (e.g. theft, prostitution) in order to cater for themselves. More so, in view of the high level of disharmony among families there is increasing unhealthy competition, jealousy, discrimination and disunity.

ii. Peer group: This is an important agency of socialization. It serves as a major source of inspiration to the adolescent on such matters as fashion, dressing, hair style, information related to sex, heterosexual friendship, leisure activities, etc. (Odunukwo, 2002).

Odunukwu (2002) argued that most of the Nigerian families have failed to cater for the basic needs of their children (food, security, love and affection) due to the high level of poverty. Consequently, peer-group influences appear to subsume those of the family. Hence, in most cases anti-social activities are learnt and emphasized in the peer group, either for the purpose of belongingness or solving their economic and social needs. Odunukwe (2002) added that those negative trends explain the increasing rate of delinquency (armed robbery, prostitution, immoral dressing, etc) among the Nigerian youth. This had surely affected the level of their dedication to academic work and other productive ventures.

\section{Recommendation:}

In view of challenges facing the physical and social learning environment in the Nigerian schools, the following are recommended in order to address the problems squarely.

i. The three tiers of government should embrace the Universal Basic Education Programme more seriously in order to improve the funding of education at the lower level. 
ii. The $26 \%$ allocation of the annual budget to education advocated by the United Nation's Scientific and Cultural Organization (UNESCO) should be adhered to in order to improve the physical condition of Nigerian schools.

iii. Nigerian governments should sincerely enact and implement economic policies that will empower households so that parents can effectively discharge their responsibilities to their children.

iv. Counselling services should be provided in schools and communities in order to rehabilitate the deviant children and adolescents.

v. Families should be counselled on the right attitude to marriage and family life in order to curb the numerous problems identified within Nigerian homes.

\section{Conclusion}

A conducive environment is a major prerequisite for the normal development of individuals. Thus, concerted effort should be made by all the stakeholders to create a favourable physical and social learning environment in order to save the youngsters from destruction. 


\section{Reference}

Adara, O.A. (1998). Environmental education in peace education at the tertiary level. Journal of Curriculum and Instruction. 2 (2): 197.

Adeniyi, E.F. (2002). Social life and classroom interactions in Nigerian schools: implications for learning. In R.U.N Okonkwo, R.O. Okoye, (Ed) The learning environment of the Nigerian child. A publication of NISEP. Awka: Erudition Publishers.

Aliyu, U.D. (2006). Introduction to Psychology of Learning. Kano: Tahir Advertising Agency.

Diehi, D.S.; Lemerise, E.A; Cavalry, S.L.; Ramsay, S. \& Roberts, J., (1998). Peer relation and school adjustment in upgraded primary school. Journal of Educational Psychology, 90: 506-515.

F.R.N. (2005). National Policy on Education. NERDC: Lagos.

Girei, A.U. \& Girei, S.B. (1995). Towards effective funding and management of primary education in Nigeria. Paper presented at the School of Education Seminar, F.C.E. Yola.

Gullies, R.M. \& Asham, A.F. (1998). Behaviour and interaction of children in cooperative group in lower and middle elementary grades. Journal of Educational Psychology, 1991, 746-757.

NPEC \& SPU (1991). Monitoring and Evaluating Report on Primary Education in Nigeria, Kaduna, Kaduna: F.M.E.

Odunukwe, G.E. (2002). The influence of social environment on the development of the Nigerian child. In R.U.N, Okonkwo, \& R.O Okoye, (Ed) The learning environment of the Nigerian child. A publication of NISEP. Awka: Erudition Publishers.

Ryan, A.M. Gheen, M.H., \& Midgley, C. (1988). Why do some students avoid asking for help? An examination of the interplay among students' academic efficacy, Journal of Educational Psychology ${ }_{2}$ 90: 528-538.

Ubah, M. C. (2002). A focus on the physical learning environment of the Nigerian primary school child. In R.U.N.; Okonkwo, \& R.O. Okoye, (Ed.) The learning environment of the Nigerian child. A publication of NISEP. Awka: Erudition Publishers.

Udeozor, R.K. (2002) Effective management of the physical learning environment: A challenge of the school administration. In R.U.N., Okonkwo, \& R.O, Okoye, (Ed.). The learning environment of the Nigerian child. A publication of NISEP. Awka: Erudition Publishers. 